\title{
СОЦИОЛОГИЯ УПРАВЛЕНИЯ
}

2020.01.017. А.А. РАРЕНКО. УСЛОВИЯ УСПЕШНОГО УПРАВЛЕНИЯ КУЛЬТУРОЙ ИННОВАЦИОННЫХ ОРГАНИЗАЦИЙ. (Обзор).

RARENKO A.A. Conditions for successful management of the culture of innovative organizations. (Review). - DOI: 10.31249/rsoc/ 2020.01.04

Аннотация. В обзоре условий успешного управления культурой инновационных организаций рассматривается стиль управления, при котором достигается максимально возможная степень инновационного мышления. Инновационное мышление, в отличие от креативного, носит прикладной характер.

Abstract. The review of the conditions for successful management of the culture of innovative organizations examines the management style in which the highest possible degree of innovative thinking is achieved. Innovative, unlike creative, thinking is of an applied nature.

Ключевые слова: организационная (корпоративная) культура; инновации; управление культурой; материальнье ценности; духовные ценности; функции организационной культуры; структура организационной культуры; носители организационной культуры;; всеобщность организационной культуры.

Keywords: organisational (corporate) culture; innovation; cultural management; material values; spiritual values; organisational culture functions; organisational culture structure; carriers of organisational culture; universality of organisational culture.

В научных кругах сегодня существует мнение, что культура в организации может рассматриваться как показатель ее способности стать инновационной. Условиями успешного управления культурой инновационных организаций следует признать такой стиль 
управления, при котором достигается максимально возможная степень инновационного мышления.

Инновационное мышление необходимо отличать от креативности; для этого исследователями выделяются следующие восемь критериев: 1) сущность; 2) продукт; 3) характерные особенности; 4) результат; 5) предпосылки формирования; 6) роль профессиональной подготовки субъекта в формировании у него творческого / инновационного мышления; 7) связь с основной деятельностью субъекта; 8) мотивация [Батоврина, 2016; Батоврина, Блохина, 2017; Батоврина, 2019; Пугачев, 2019]. В отличие от креативного мышления, в результате которого порождается нечто новое, ранее не существовавшее, при инновационном мышлении формированию нового сопутствует его успешное применение на практике. Созданный продукт обязательно сопровождается разработкой технологии, способом ее реализации.

Креативное мышление характеризуется интуитивностью, иррациональностью, спонтанностью, масштабностью, отсутствием границ творческого поиска, в то время как характеристиками инновационного мышления являются: 1) сочетание интуиции и логики, при этом большое внимание уделяется рациональности; 2) прагматичность, ориентация на получение результатов; 3) тесная связь с основным полем деятельности субъекта творчества; 4) творческий поиск в пределах ранее установленных границ - чаще всего сферы профессиональных интересов новатора [Батоврина, 2014; Батоврина, Блохина, 2017, с. 128]. Результат креативного мышления часто носит неожиданный, непрогнозируемый характер, результат инновационного мышления - напротив, ожидаемый, прогнозируемый. Для формирования креативного мышления необходимо только воображение и фантазия, в то время как для инновационного - воображение и фантазия, сопровождаемые логикой, знаниями и опытом.

Профессиональная подготовка не имеет значения для креативного мышления, но принципиально важна для инновационного. В то же самое время креативное мышление не связано, а инновационное - напротив, неразрывно связано с конкретным видом профессиональной деятельности.

Что касается мотивации, то в случае креативного мышления главным стимулом для субъекта творчества, как правило, выступает сам творческий процесс, а человек испытывает удовольствие от 
занятий творческой деятельностью как таковых, зачастую не придавая особого внимания получаемому результату. Особенностью инновационного мышления следует считать то, что главным стимулом для субъекта является стремление к достижениям, а человек испытывает удовлетворение, прежде всего, от полученного результата [Батоврина, Блохина, 2017, с. 128]. Таким образом, инновационное мышление в отличие от креативного носит прикладной характер, оказывается ориентированным на результат, связь с профессиональной деятельностью субъекта.

Согласно статистическим данным, количество инновационных организаций в мире с каждым годом неуклонно растет, в том числе и в России, и довольно высокими темпами. Соответственно, прямым следствием увеличения числа инновационных организаций является усиление интереса к проблемам управления персоналом, занятым в инновационной сфере. Основная проблема, по мнению специалистов, заключается в формировании и дальнейшем развитии инновационного потенциала организаций.

Решение данной проблемы требует выработки особых подходов к подбору, оценке, мотивации и обучению персонала. Значимую роль в развитии инновационного потенциала играет и формирование уникального организационного климата, стимулирующего творческую активность сотрудников. Признание организационного климата весомым фактором развития инновационного потенциала организации - итог многочисленных междисциплинарных исследований на стыке психологии, социологии и управленческих наук, проведенных в последние десятилетия. К числу их важнейших результатов исследователи относят следующие.

1. Констатация значимости организационного климата для инновационной организации.

2. Выделение двух уровней климата, влияющего на инновационный потенциал организации: внешнего и внутреннего. Внешний климат (или внешняя среда) организации - результат функционирования социальных институтов (института образования, института культуры и др.). Он стимулирует развитие инновационного потенциала организации за счет приоритетного использования денежных, властных, законодательных и иных ресурсов государства. Внутренний климат организации - продукт, возникающий в результате желания, а также готовности руководства организации 
обеспечить необходимые условия для инновационной деятельности в соответствии с целями развития предприятия.

3. Выявление и описание признаков организационного климата, влияющего на инновационную активность персонала, среди которых - обмен знаниями в организации, атмосфера доверия и взаимоподдержки в коллективе, открытость изменениям, терпимость руководства к ошибкам сотрудников и пр.

4. Разработка инструментария для оценки организационного климата с позиции его влияния на инновационную активность персонала и инновационный потенциал организации в целом [Assessing the work ..., 1996].

Анализ успешного опыта управления персоналом и культурой инновационных организаций (DELL, Google, AT\&T, Austal, Cisco, Hewlett Packard и др.) позволяет специалистам выделять следующие базовые направления формирования и развития организационной культуры инновационного типа: 1) создание уникальной среды для творчества и инноваций путем изменения дизайна офисных и иных помещений; 2) материальная и нематериальная мотивация сотрудников к выработке и реализации инновационных идей (проведение конкурсов новаторских идей и рационализаторских предложений, материальное поощрение сотрудников, организация корпоративных конференций, семинаров и пр.); 3) непрерывное обучение и развитие персонала, участие сотрудников в мастерклассах, тренингах, дискуссиях, как в роли обучаемых, так и в роли обучающих; 4) создание так называемых порталов знаний, корпоративных библиотек; разработка дистанционных программ обучения; 5) формирование внутрикорпоративных профессиональных площадок с целью обмена мнениями и знаниями между сотрудниками компании; 6) гибкий график работы сотрудников, позволяющий высвобождать время для самообучения и саморазвития [Батоврина, 2019, с. 95-101].

Важнейшим дополнением к перечисленным направлениям формирования, развития и успешного функционирования инновационной культуры организаций является внедрение в них концепции инновационного лидерства. По мнению ряда исследователей, оно придает динамизм организационной жизни сотрудников, способствует формированию атмосферы свободы и доверия в коллективе, поощряет неформальное общение между коллегами и тем са- 
мым повышает инновационную активность персонала [Батоврина, 2019, c. 100].

\section{Список литературы}

Батоврина E.B. Управление персоналом инновационных организаций. М.: АРГАМАК-МЕДИА, 2019. - 134 с.

Батоврина E.B. Основные направления развития инновационного мышления студентов вузов // Вопросы гуманитарных наук. - М., 2014. - № 6. - С. 98101.

Батоврина E.B. Формирование и развитие инновационной культуры организации // Материалы Международной научно-практической конференции «Творческое наследие А.С. Посникова и современность в рамках программы "Возвращенные имена": IX Посниковские чтения». - Смоленск: Изд-во СмолГУ, 2016. C. 11-16.

Батоврина Е.В., Блохина М.С. Развитие инновационного мышления персонала в процессе профессиональной подготовки // Вестник Нижегородского университета им. Н.И. Лобачевского. Серия: Социальные науки. - Нижний Новгород, 2017. - № 4. - С. 126-134.

Пугачев В.П. Управление персоналом организации. - М.: Юрайт, 2019. $402 \mathrm{c}$.

Assessing the work environment for creativity / Amabile T., Conti R., Coon H., Lazenby J., Herron M. // The Academy of management j. - Briarcliff Manor (NY), 1996. - Vol. 39, N 5. - P. 1154-1184. 